Journal

of Geography

Politics and Society

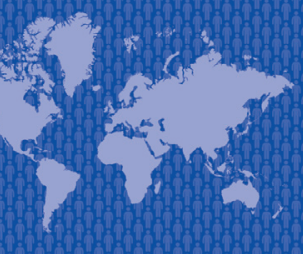

7(1)/2017

\section{Journal of Geography, Politics and Society}

$2017,7(1), 24-38$

DOI 10.4467/24512249JG.17.004.6203

\title{
CHANGES IN THE HEALTH SITUATION OF THE POPULATION OF POLAND FOLLOWING THE ACCESSION TO THE EUROPEAN UNION (COMPARED TO CENTRAL AND EASTERN EUROPEAN COUNTRIES)
}

\author{
Elżbieta Grzelak-Kostulska (1), Natalia Sypion-Dutkowska (2), Tomasz Michalski (3) \\ (1) Department of Urban Studies and Regional Development, Nicolaus Copernicus University, Lwowska 1, 87-100 Toruń, Poland, \\ e-mail: grzelak@umk.pl \\ (2) Spatial Management Unit, University of Szczecin, Mickiewicza 18, 70-383 Szczecin, Poland, \\ e-mail: natalia.sypion@usz.edu.pl \\ (3) Institute of Geography, University of Gdańsk, Bażyńskiego 4, 80-309 Gdańsk, Poland, \\ e-mail: tomasz.michalski@ug.edu.pl
}

\section{Citation}

Grzelak-Kostulska E., Sypion-Dutkowska N., Michalski T., 2017, Changes in the health situation of the population of Poland following the accession to the European Union (compared to Central and Eastern European countries), Journal of Geography, Politics and Society, 7(1), 24-38.

\section{Abstract}

The main objective of study is to present the health situation of the inhabitants of Poland. This was accomplished both in temporal and spatial depiction. The secondary goal is to show the health situation in Poland in comparison to other European post-Communist countries. To describe the health situation five variables are used: crude death rate, infant mortality, incidence of tuberculosis, incidence of HIV/AIDS, and life expectancy.

The changes in the health situation in Poland are generally positive. Infant mortality and the incidence of tuberculosis are declining and the average life expectancy (for both sexes) is extending. Worrisome is the increase in the number of seropositive persons, but this is not accompanied by an increase in the incidence of AIDS. Also an increase in mortality is on the rise, but this process can be associated with the society's ageing. The spatial differentiation of the health situation in Poland is significant, the most pronounced in the case of infant mortality (taking NUTS-4 as the base unit).

Comparing to European post-Communist countries, the health situation of the Polish society can be considered relatively good (the worst in the case of tuberculosis).

\section{Key words}

health situation, crude death rate, infant mortality, incidence of tuberculosis, incidence of HIV/AIDS, life expectancy, Poland.

\section{Introduction}

The health situation of the Polish population is subject to relatively large changes. On the one hand, this results from the processes taking place in all of Europe that have an impact on the health situation of the population, such as changes in health behaviours, progress in health care or ageing of the population. On the other hand, it is influenced by factors specific to European post-Communist countries and 
related to the impact of transformation processes on health or to high emigration (especially from the new member states of the European Union).

The main aim of the study is to present changes in the health situation of the population of Poland since its accession to the European Union to the present day. The secondary objective is to present the current spatial differentiation in the population's health situation. In any analysis of the health level almost always the so-called negative health indicators are used. This is also the case here. The available data on mortality (the crude death rate and infant mortality), the incidence of selected diseases (there is a wide range of diseases that can function as indicators of the society's health condition; most commonly the so-called social diseases or civilization diseases are taken into account in analysis - the present study has been limited to two: tuberculosis and HIV/AIDS) and life expectancy (by gender).

The statistical data used in the paper come from reports and databases, both Polish (the Central Statistical Office of Poland, the Institute of Tuberculosis and Lung Diseases, the National AIDS Centre) and foreign institutions (the WHO Regional Office for Europe, the World Bank). However, the final results of the analysis are somewhat distorted by the fact that when calculating the number of deaths or disease incidence per number of inhabitants, the official data provided by the Central Statistical Office of Poland were used, in accordance with which emigrants were included among inhabitants of Poland (regardless of the time spent out of the country), while according to estimates, at the end of 2015 as many as 2.4 million inhabitants of the country stayed outside Poland (Informacja..., 2016). The available statistics on temporary emigration does not allow for eliminating the impact of the observed differences.

Conventional statistical methods were applied in the paper, such as regression models, the coefficient of variation (CV) and Pearson correlation coefficient (PCC).

\section{Changes in mortality}

After its accession to the European Union, we can distinguish two periods of changes in mortality (Fig. 1) in Poland. In 2004-2009 a very clear upward trend was observed, while in the period of 20092014 large fluctuations were noted, with no clear changing trend. Relatively high mortality rates for 2015 , amounting to 10.3 deaths per 1,000 inhabitants may be either a continuation of fluctuations from 2009-2014 or a beginning of a new upward trend. A slowly decreasing level of infant mortality ${ }^{1}$ on the one hand and constant ageing of the population on the other hand suggest that the slight growing trend in the intensity of mortality (presented in Fig. 1) will become more distinct ${ }^{2}$, even despite the further improvement in the country's situation in terms of its health. Regarding gender, a higher level of mortality among men than among women can be seen throughout the whole period. However, a reduction in the difference should be considered as a positive process, as in 2004 it was $1.9^{3}$ deaths per 1,000 people of one sex, while in 2015 it was $1.4^{4}$. This difference will be discussed in greater detail in the analysis of life expectancy.

With a breakdown by urban and rural population, one can notice major changes. In 2004, higher mortality rates were among the rural population (10.0 deaths per 1,000 inhabitants) than among the urban one (9.2), but in 2014 the mortality rate in the rural population remained at the same level, while in the urban one it increased to 10.4 deaths per 1,000 inhabitants.

The diversity of mortality rates in Poland in 2014 in spatial depiction (breakdown by poviats (NUTS4)) is shown in fig. 2. With the values for Poland at 9.8 deaths per 1,000 inhabitants, it varied from 6.0 in the Kartuzy poviat to 15.7 in the Hajnówka poviat (BDL GUS, 2016), and it was rather little diversified, as the $\mathrm{CV}$ value amounted to $15.1 \%$. In Fig. 2 one can see two general patterns. The first one partly results from history - in its effect areas of the former Russian partition and the Sudetes with adjacent areas manifest higher mortality rates. The second one is a consequence of the most modern processes - stemming from migration to suburban zones from major cities and an increasing percentage of the elderly in those cities, which results in an elevated death rate, while it is quite the opposite in suburban areas. Fig. 2. shows this especially clearly in the case of the Warszawa, Poznań, and Wrocław agglomerations.

In 2004-2014 there were minimal changes in the structure of deaths ${ }^{5}$. In 2004 there were 363,500 deaths, of which $46.4 \%$ accounted for diseases of the circulatory system $\left(100-199^{6}\right)$ and $25.3 \%$ for neo-

\footnotetext{
1 In 2004, the infant mortality rate per 1,000 live births was 6.8; in 2014 it was 4.2 (Bank Danych Lokalnych GUS).

2 Unless immigrants at a young age will come to Poland in large numbers.

3 For women the rate was 8.6 deaths per 1,000 people, and for men 10.5 (Bank Danych Lokalnych GUS).

4 For women the rate was 9.6 deaths per 1,000 people, and for men 11.0 (Bank Danych Lokalnych GUS).

5 This is confirmed by the value of the similarity of structures coefficient, which is 1.00 .

6 ICD-10 (International Statistical..., 2016).
} 


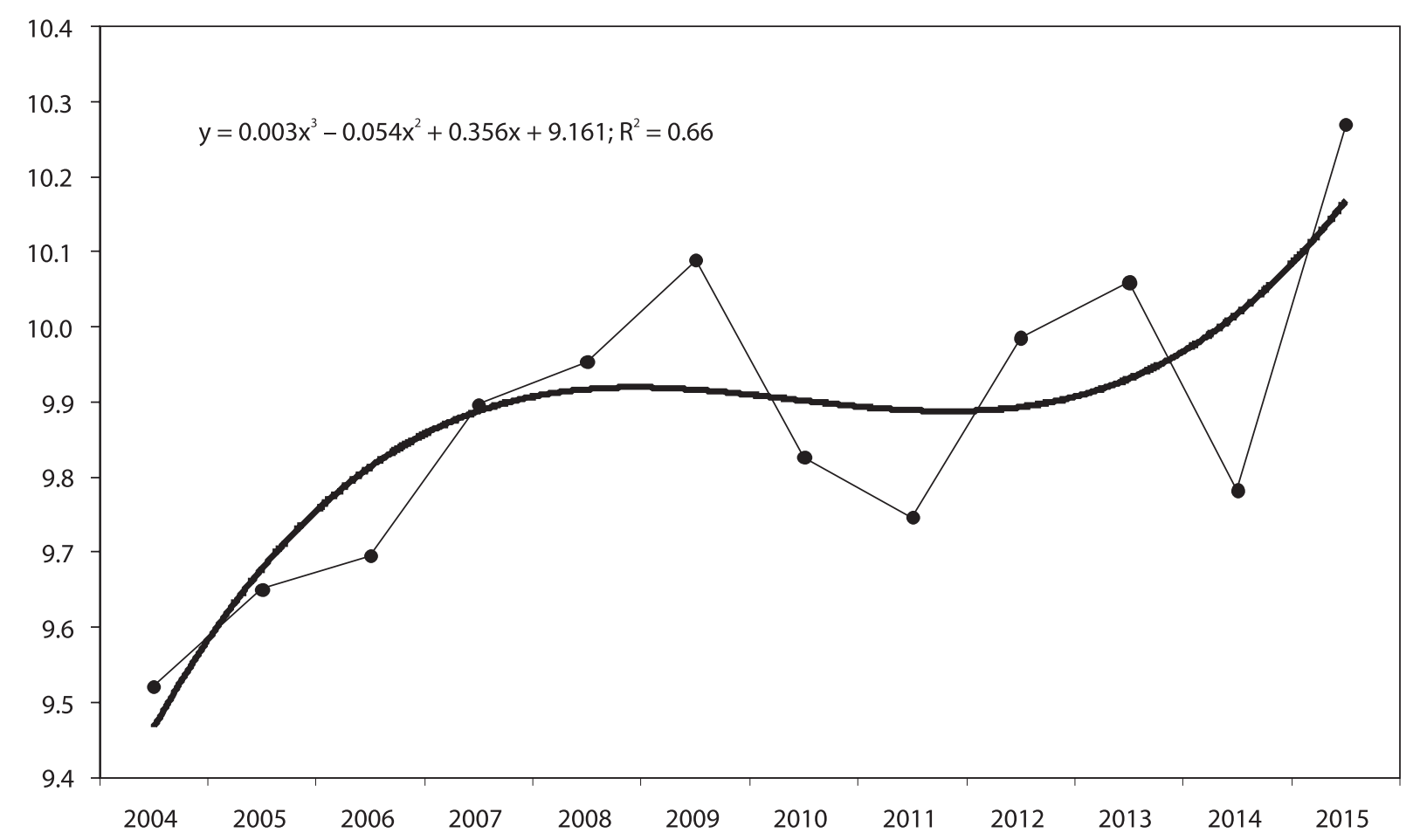

Fig. 1. The mortality rate per 1,000 inhabitants in Poland in 2004-2015

Source: own study based on Bank Danych Lokalnych GUS.

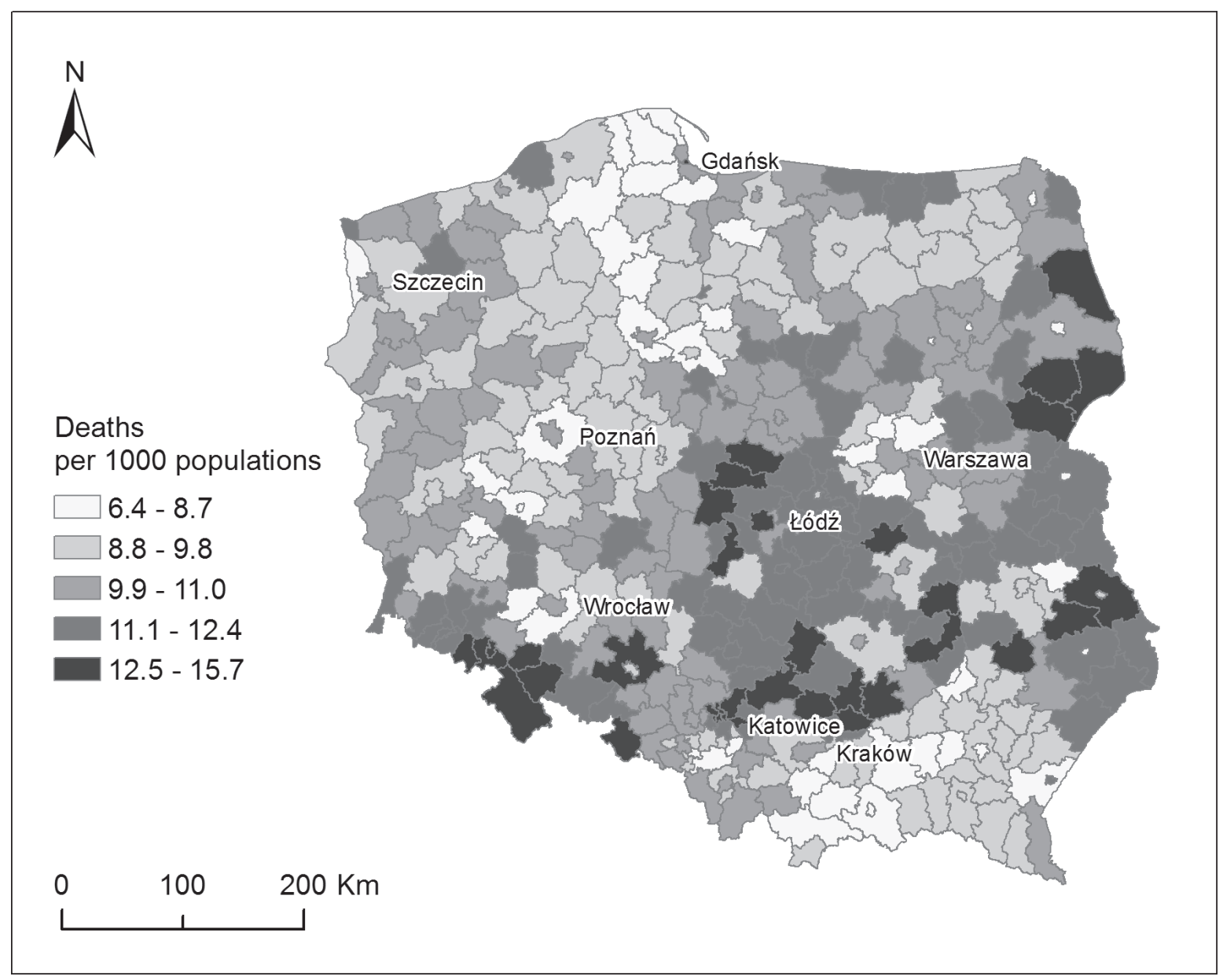

Fig. 2. Spatial differentiation of the intensity of mortality per 1,000 inhabitants in Poland in 2014 broken down by poviats (NUTS-4)

Source: own study based on Bank Danych Lokalnych GUS. 


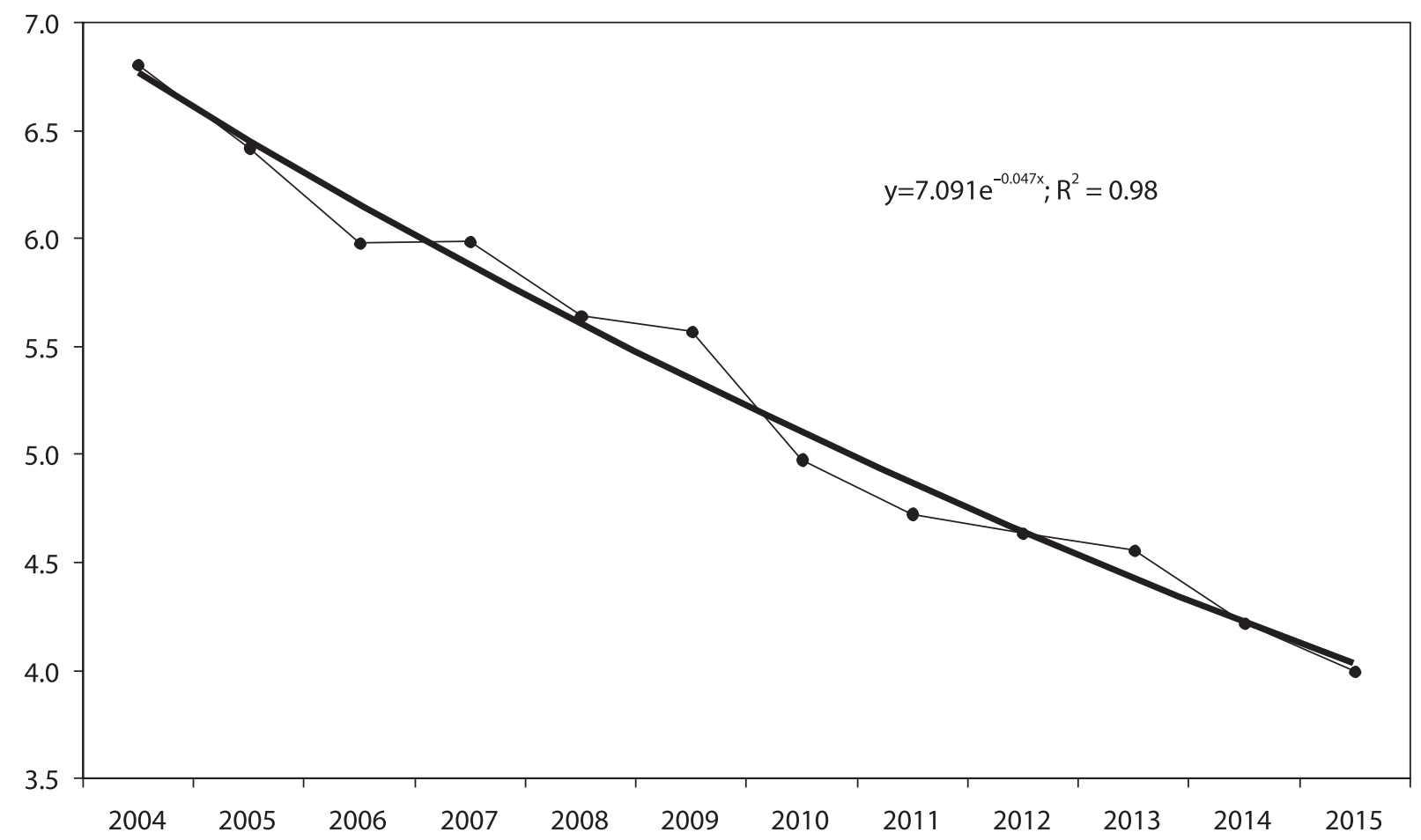

Fig. 3. The level of infant deaths per 1,000 live births in Poland in 2004-2015

Source: own study based on Bank Danych Lokalnych GUS.

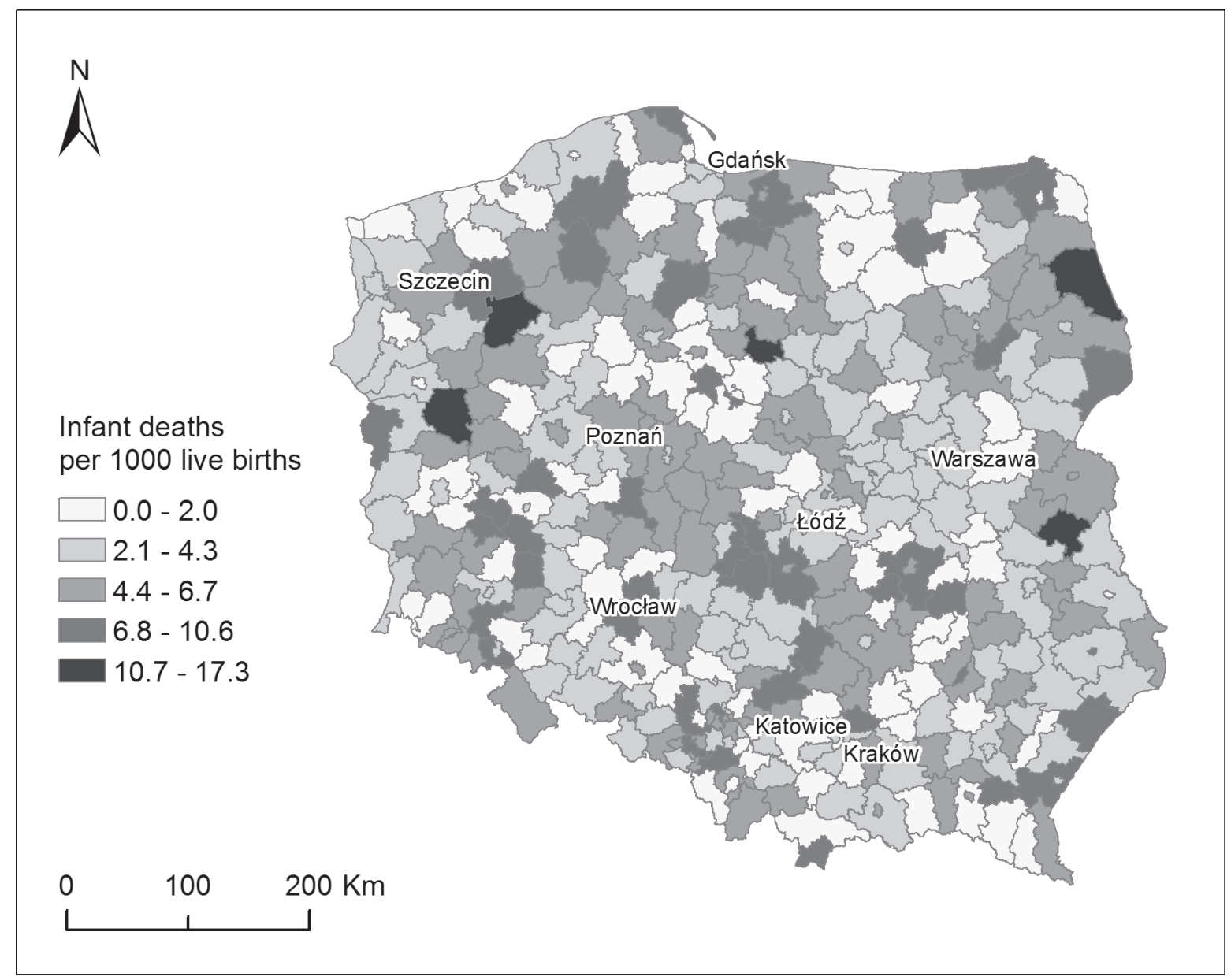

Fig. 4. Spatial differentiation of the intensity of infant deaths per 1,000 live births in Poland in 2014 broken down by poviats (NUTS-4).

Source: own study based on Bank Danych Lokalnych GUS. 
plasms (C00-D48). Ten years later, among 376,500 deaths, it was $45.1 \%$ and $26.6 \%$, respectively. The following groups of diseases also had a greater share in the structure of deaths: symptoms, signs and abnormal clinical and laboratory findings, not elsewhere classified (R00-R99) - 6.6\% in 2004 and 7.4\% in 2014, external causes of morbidity and mortality (V01Y98) - respectively: $6.9 \%$ and $5.7 \%$, diseases of the respiratory system (J00-J99) - respectively: $4.6 \%$ and $5.4 \%$, diseases of the digestive system (K00-K93) respectively: $4.3 \%$ and $4.1 \%$ (Baza Demografia GUS).

Infant mortality is considered to be a fairly accurate indicator of the population's health situation, since its level is influenced by many factors related to the parents' pro-health behaviours (especially of mothers during pregnancy), living conditions and the quality of the medical care of the pregnant woman and then of an infant (cf. Masuy-Stroobat, 2006; Szczyt, 2006). Fig. 3. shows changes in the number of infant deaths per 1,000 live births. We can see a very stable trend of reducing the intensity of infant deaths, which however slowly begins to level off. The stability of changes is also evidenced by small fluctuations in the share of neonatal and post-neonatal deaths. In $2004,71.7 \%{ }^{7}$ of infant deaths were neonatal deaths, and in 2015 it was $72.3 \%{ }^{8}$.

One can notice major changes in a breakdown by urban and rural populations. In 2004, the urban population manifested a higher rate of infant mortality (7.1 deaths per 1,000 live births) than the rural one (6.4); in 2015 the situation was reversed - the level of infant mortality in urban areas (4.0) was slightly lower than in the rural ones (4.1) (Baza Demografia GUS).

In spatial depiction (breakdown by poviats (NUTS-4)), the diversity of the infant mortality rate in Poland in 2015 was significant, because the CV value amounted to $64.5 \%$. With the mean value for the country at 4.0 deaths per 1,000 live births, it ranged from no infant deaths (such a situation was recorded in 34 poviats) to as many as 17.3 deaths per 1,000 live births in the Rypin poviat (Baza Demografia GUS).

\section{Changes in the incidence of selected disease}

The incidence of tuberculosis (A15-A19) is related to the level of the society's wealth, especially housing and sanitary conditions of the population and the degree of satisfying nutritional needs (in the sense

\footnotetext{
7 It differed slightly between the sexes, as it was $69.0 \%$ for girls and $73.8 \%$ for boys (Baza Demografia GUS).

8 It differed slightly between the sexes, as it was $69.5 \%$ for girls and $74.5 \%$ for boys (Baza Demografia GUS).
}

of a lack of hunger). Preventive efforts also have an impact ${ }^{9}$. An improvement in living conditions in economically-developed countries has caused a reduction in the risk of the disease; unfortunately, crises trigger the opposite effect. Also the emergence of tuberculosis strains resistant to antimycobacterial drugs and the development of the HIV/AIDS epidemic are bringing a renewed increase in tuberculosis incidence (Zielonka, 2014; Sonnenberg et al., 2005; Szczuka, 2000).

Analysing changes in the level of tuberculosis incidence in Poland we see a clearly weak downward trend, disturbed only in 2011 by a slight increase (Fig. 5), as a result of which the number of new cases decreased from 24.9 in 2004 to 16.7 per 100,000 population in 2015.

Analysing the diversity of the situation in 2015 in the spatial depiction (a breakdown by voivodships, NUTS-2 (Fig. 6), we find that it was highly heterogeneous, as the CV value was $31.0 \%$. The lowest level of morbidity was noted in the relatively wealthy Wielkopolskie Voivodship (8.3), but it was followed by the considered as poor Warmińsko-Mazurskie Voivodeship (9.3). By contrast, the worst situation was reported in the highly urbanised and wealthy Śląskie Voivodship (26.5) (Gruźlica..., 2016). Since the obtained results partly contradict theoretical considerations, one should presume that there are also other factors affecting the recorded level of tuberculosis incidence.

The level of diagnosed cases of HIV in Poland has shown an upward trend which slowly levels off (Fig. 7). It increased from 1.72 cases per 100,000 population in 2004 to 3.38 in 2011, and in 2014 it was 3.31. In 2015 men accounted for $84.1 \%$ of new infections, women $14.5 \%$, and for $1.4 \%$ there was no data (Zakażenia...).

Although the level of AIDS (B20-B24) incidence in Poland in 2004-2014 shows large year-on-year fluctuations, one cannot see that is has increased or decreased (Fig. 7) as it has continually remained around the value of 0.34 per 100,000 population. In the analysed period the minimum was recorded in 2006 (0.31), and the maximum in 2011 (0.69). According to data, the number of AIDS cases amounted to 129 cases in 2015, of which $70.3 \%$ were males and the rest females. 40 deaths due to AIDS were reported, of which $72.5 \%$ were men and the rest females (Zakażenia...).

Analysing the diversity of the situation in 2015 in the spatial depiction (a breakdown by voivodships,

\footnotetext{
9 In accordance with the Preventive Vaccination Programme, in Poland the BCG vaccine is mandatory only for infants (Komunikat..., 2015)
} 


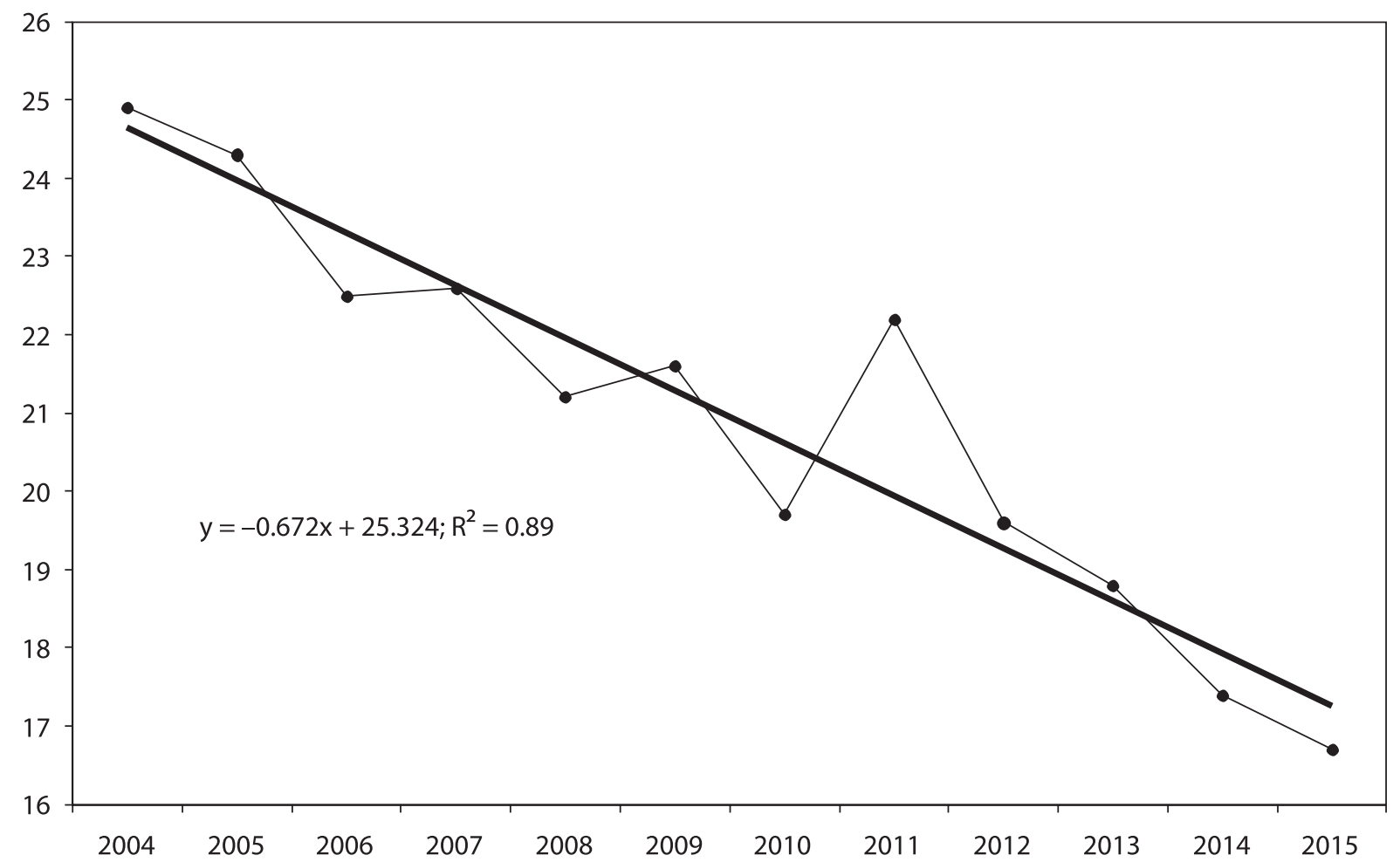

Fig. 5. Tuberculosis notification rates per 100,000 population in Poland in 2004-2015

Source: own study based on Gruźlica..., 2016.

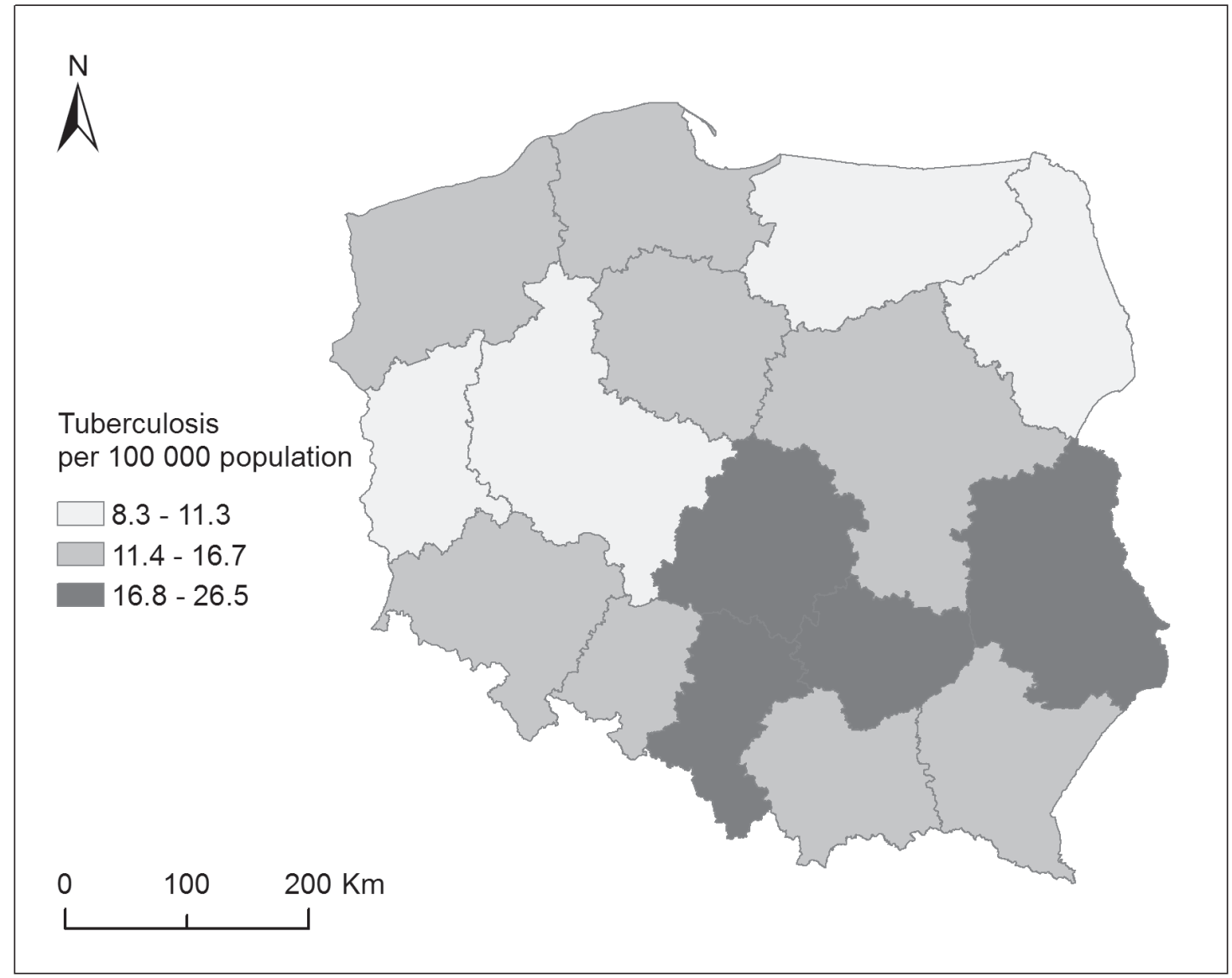

Fig. 6. Spatial differentiation of the intensity of tuberculosis notification rates per 100,000 population in Poland in 2014 broken down by voivodeships (NUTS-2)

Source: own study based on Gruźlica..., 2016. 




Fig. 7. Level of incidence of HIV and AIDS per 100,000 population in Poland in 2004-2014

Source: own study based on Zakażenia HIV i zachorowania na AIDS w Polsce.

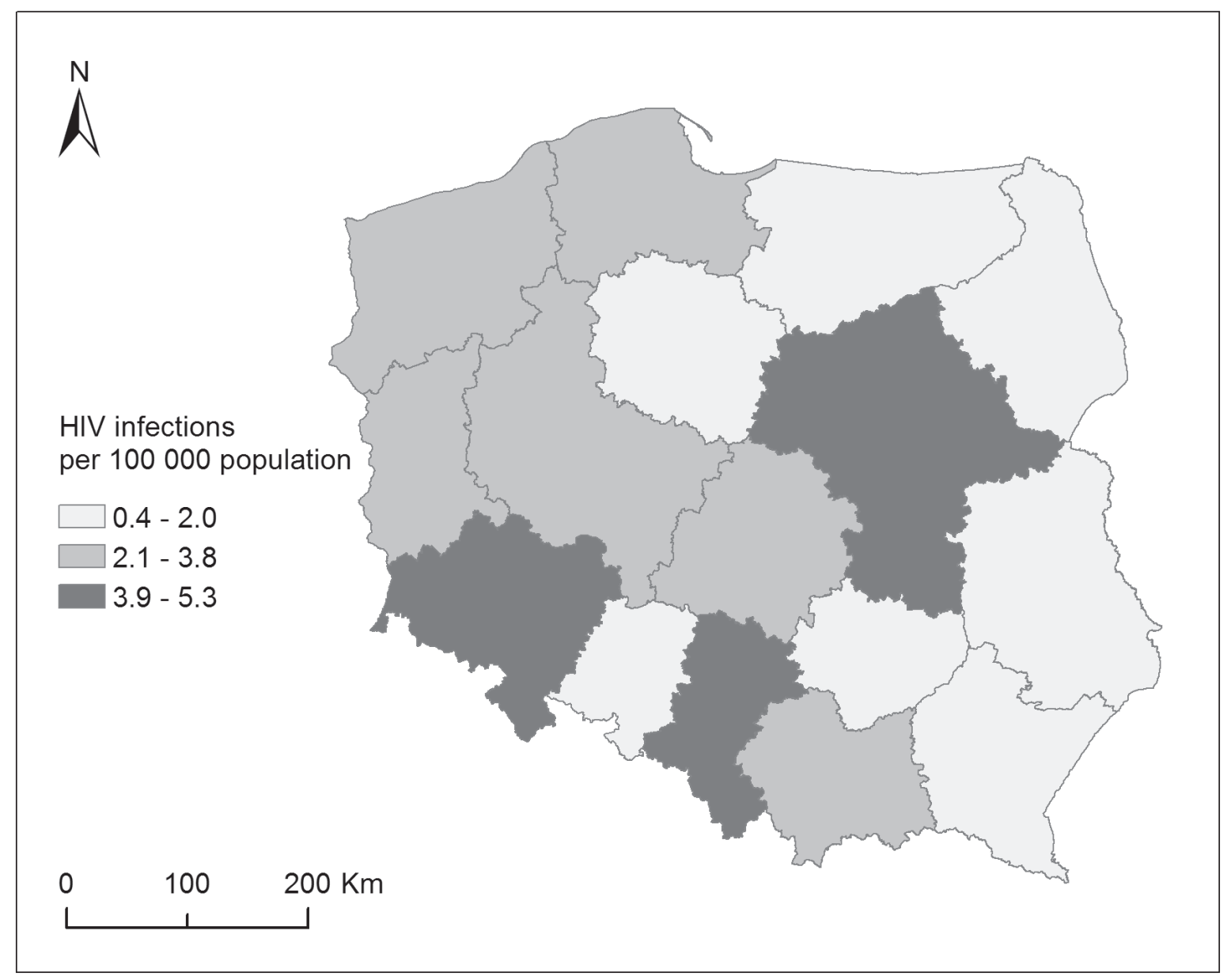

Fig. 8. Spatial differentiation of the intensity HIV infections notification rates per 100,000 population in Poland in 2014 broken down by voivodeships (NUTS-2)

Source: own study based on Zakażenia HIV i zachorowania na AIDS w Polsce. 


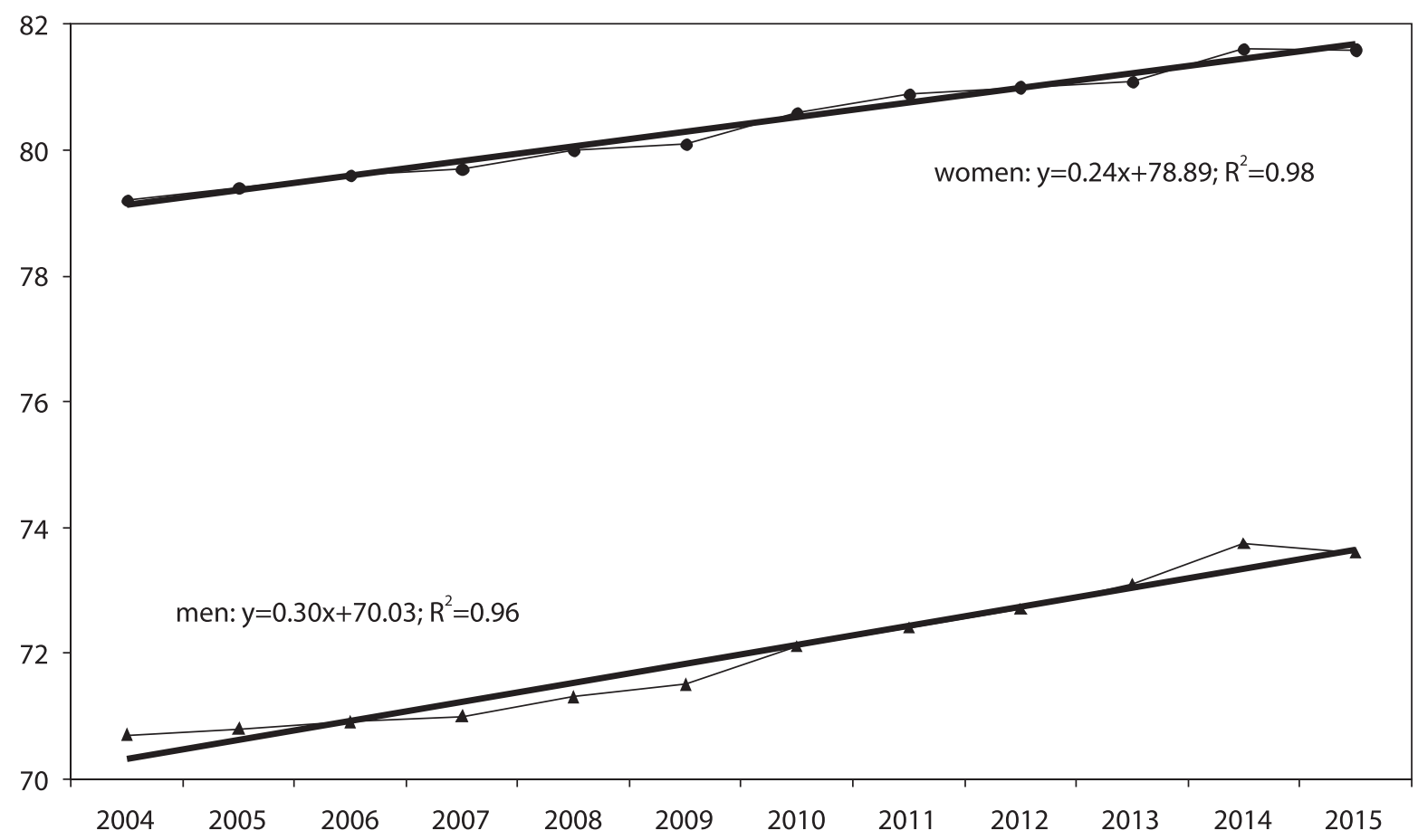

Fig. 9. The average life expectancy of females and males [in years] being of 0 years of age in Poland in 2004-2015

Source: own study based on Bank Danych Lokalnych GUS.

NUTS-2 (Fig. 8), we find that it was very highly heterogeneous, as the CV value was $49.1 \%$. In terms of spatial depiction (Fig. 8), the most new HIV infections were found in Śląskie (5.3 per 100,000 population), Dolnośląskie (4.5) and Mazowieckie Voivodships (4.1), the least in Lubelskie (0.4). But it must be kept in mind that for up to $4.6 \%$ of registered infections there are no data on the place of residence.

It is slightly different in the case of AIDS incidence. Here in 2015, the situation in breakdown by voivodeships was even more diverse $(\mathrm{CV}=79.3 \%)$. It was the worst in the Dolnośląskie (0.93 per 100,000 population), Podlaskie (0.76) and Pomorskie (0.61) Voivodeships. The best was in Małopolskie (0.03) and Lubelskie (0.05) (Zakażenia...).

\section{Change in the average life expectancy}

Biological determinants alone make the average life expectancy of males shorter than of females by one year to two years (Abdulraheem et al., 2011; Luty, 2003; Ram, 1993). Larger differences are already conditioned by non-biological factors. In Poland in 2004-2015 the average life expectancy of a male at the time of birth was as many as almost 9 years shorter than of a female. However, there are two positive trends which can be noted in Fig. 9. Firstly, there is a steady increase in further life expectancy for a person born in a given year ${ }^{10}$. Secondly, although very slow, there is bridging of differences between the two sexes ${ }^{11}$ (from 8.5 years in 2004 to 8.0 years in 2015).

The average life expectancy of males at the time of birth in rural areas is still shorter than in cities and, unfortunately, this difference is increasing, as in 2004 it was 70.3 years and 70.9 years, respectively, and in 2015 it was already 73.0 and 74.0 years. Therefore, the difference to the detriment of men living in the countryside increased from 0.6 to 1.0 year. The opposite situation is in the case of the average further life expectancy for women at the time of birth. In 2004 women in rural areas could expect to live 79.5 years and in the cities 79.1 years. In 2015 it was 81.7 years and 81.5 years, respectively. This means that the difference with the advantage for those living in the countryside still remained, but it decreased from 0.4 to 0.2 year (Bank Danych Lokalnych GUS).

Fig. 10 illustrates the spatial differentiation of the average life expectancy of women [in years] born in 2015 in a breakdown by NUTS-3. Extreme values are designated by the Katowice (78.9 years) and Siedlce (83.0 years) sub-regions (Bank Danych Lokalnych

10 For men born in 2015, it was longer by 2.9 years than for men born in 2004. For women it was respectively longer by about 2.4 years (Bank Danych Lokalnych GUS).

11 As evidenced by the coefficient values at 0.235 with the regression line for women and at 0.302 with the regression line for men. 


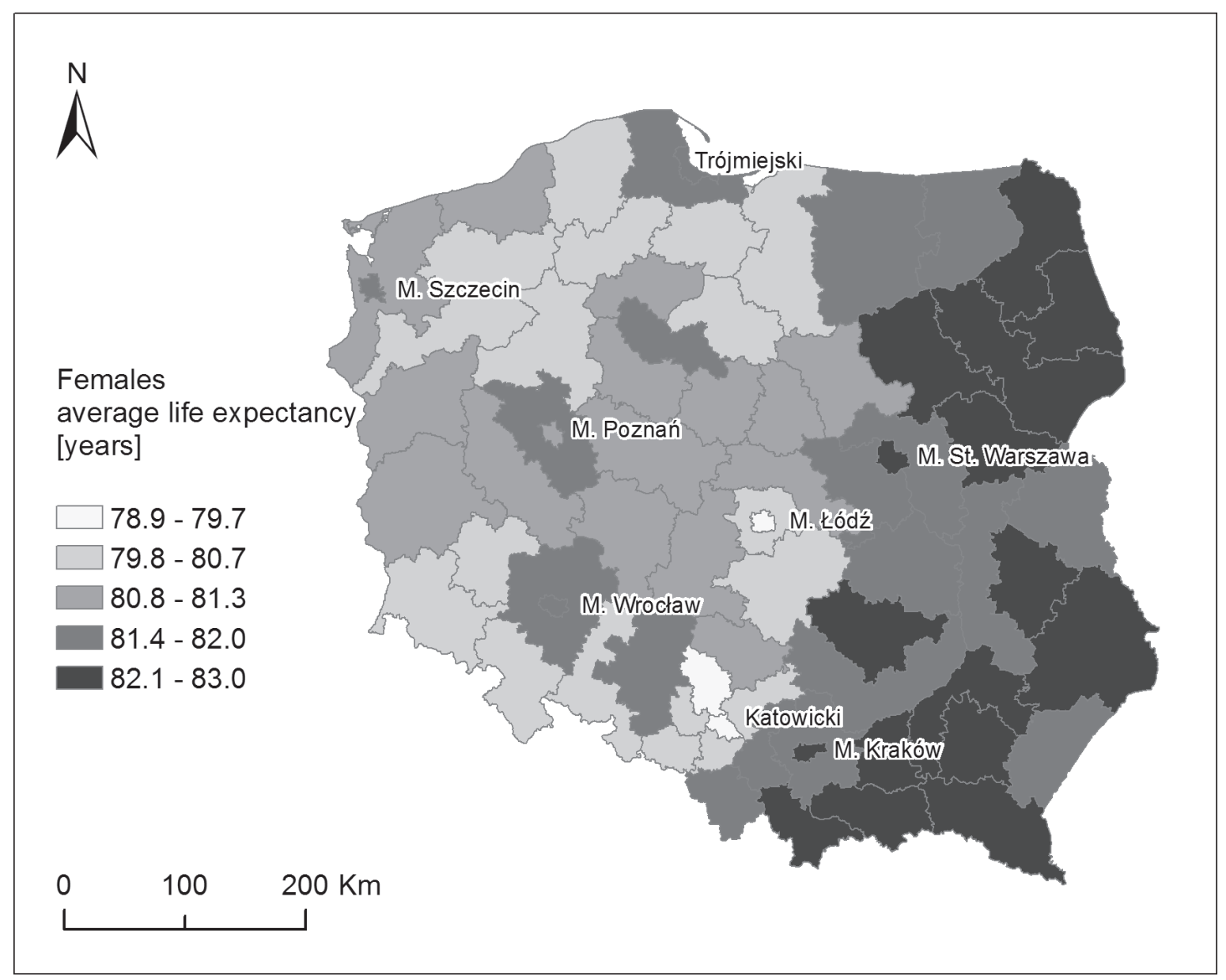

Fig. 10. Spatial differentiation of the average life expectancy of females [in years] being of 0 years of age in Poland in 2015 by NUTS-3 regions

Source: own study based on Bank Danych Lokalnych GUS.

GUS), and the diversity of situations is very small (CV=1.0\%). Looking at Fig. 9, we see two spatial regularities. Firstly, a slightly worse situation is characteristic of numerous urban sub-regions, especially Łódź and Górny Śląski. However, there are exceptions which include Warsaw, Kraków, Szczecin. Secondly, a better situation is clearly visible in the east of Poland, especially in the voivodeships: Podlaskie, Podkarpackie, Małopolskie and, to a lesser extent, Lubelskie, Świętokrzyskie and in the east of Mazowieckie.

In turn, Fig. 11 illustrates the spatial variation of average life expectancy of men [in years] born in 2015 broken down by NUTS-3. The extreme values are designated by the Piotrków (70.8 years) and Krakow (76.3 years) sub-regions (Bank Danych Lokalnych GUS). Although the diversity of situations is also very small $(C V=1.6 \%)$, it is still significantly higher than in the case of women. In the case of men there are not so clear spatial regularities as in the case of women. In general, one can conclude that longer average life expectancy occurs in the sub-regions that contain large cities (with the exception of Łódź and Górny Śląsk) and in Galicia.
Comparing differences in the average life expectancy between women and men, we find that at the average value for a person born in 2015 of 8.0 years to the detriment of men, the extreme values were set by the Tricity and Tychy (5.9) and Siedlce (10.4) sub-regions. The diversity of situations was already high, because the CV amounted to $12.1 \%$. In spatial depiction, the smallest differences between the two sexes occurred in most sub-regions containing large cities. The fact that the spatial situation of both sexes in the analysed period differs from each other is best proved by PCC, which is only 0.59 .

\section{Situation in Poland in comparison to European post-communist countries}

Poland belongs to the group of European post-Communist countries in which economic, social and political reforms have been successfully implemented (Balázs et al, 2014; Bąk, 2006; Michalski, 2006; Staehr, 2011; Sztompka, 2004). In countries where no formal transformation took place or it was ineffectually 


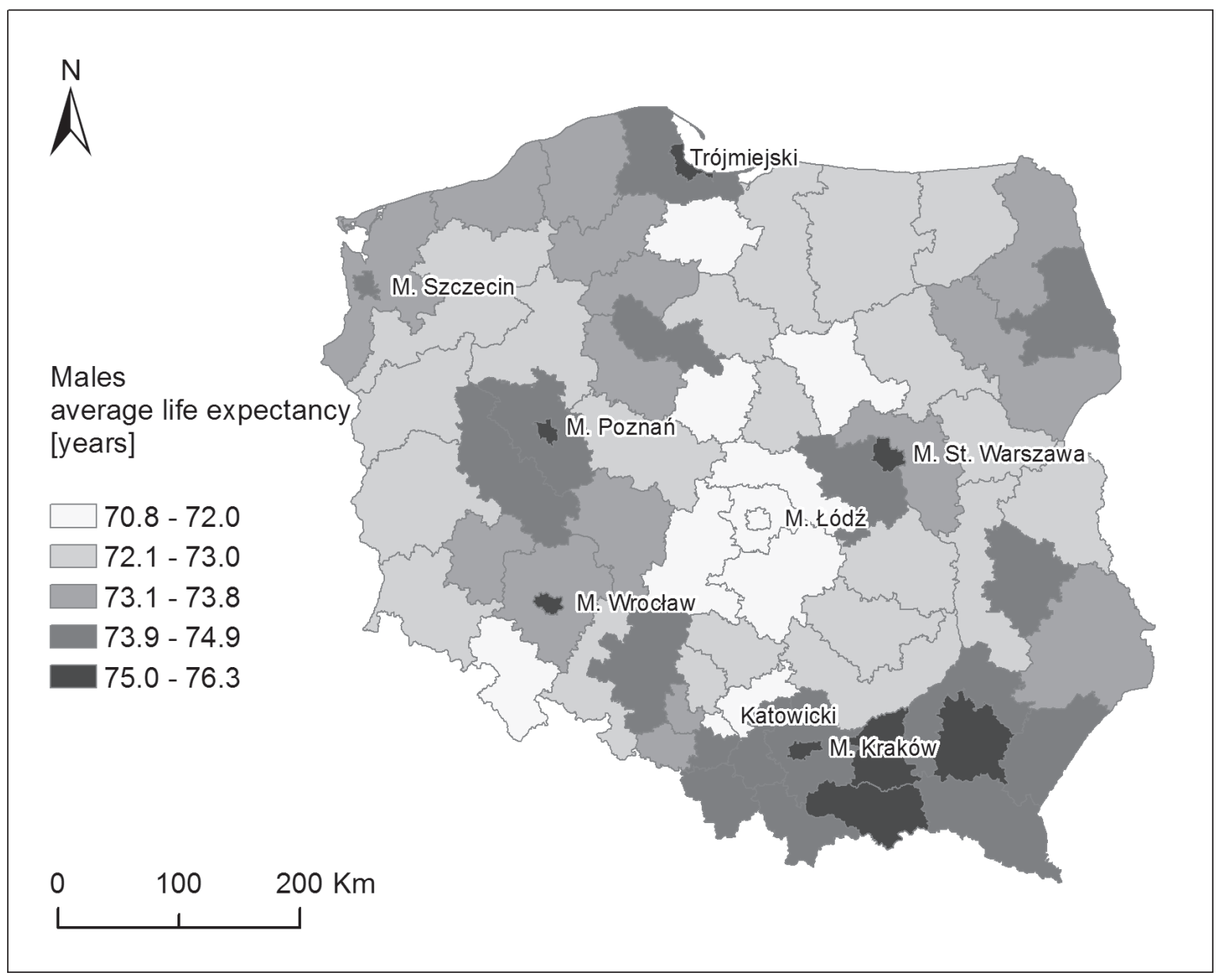

Fig. 11. Spatial differentiation of the average life expectancy of males [in years] being of 0 years of age in Poland in 2015 by NUTS-3 regions

Source: own study based on Bank Danych Lokalnych GUS.

conducted, there is a whole range of factors negatively affecting the population's health situation (cf. Bobak et al., 2000; Brainerd, 1998; Domański, 2005; Florescu-Ciobotaru, 2006; Hu et al., 2015; Shakarishvili (ed.), 2005).

Although the standardized death rate could better reflect the impact of successful reforms on changes in the mortality level, as it does not take into account the impact of the population's age structure, it was decided that showing the actual level of mortality would be more important, hence the indicator: crude death rate per 1,000 people was selected (Fig. 12). Comparing to other analysed countries, Poland is in a relatively favourable position. Nevertheless, differences in the level of the analysed mortality is a derivative of the diversity of the age structure and the advancement of the transformation process. The lowest level of mortality is in the countries that successfully introduced reforms (Slovenia, Slovakia, Poland, Czechia), but also those with a young society (Albania, Macedonia, Montenegro) (see: Grzelak-Kostulska et al., 2012a, 2012b; Meslé, 2004; Michalski, 2012a, 2012b, 2016; Philipov, Dorbritz, 2003).
Again, in comparison to the analysed group of countries, in 2015 Poland was characterised by a relatively low level of infant mortality rate per 1,000 live births (Fig. 13). Although in all European postCommunist countries a decline in infant mortality was recorded, but in those with a bad economic, social and political situation, it is still very high (see: Aleshina, Redmond, 2005; Michalski, 2010, 2012b, 2016; Pietrzyka, Gadzinowski, 2007; Zatoński et al., 2006; Zetlin et al., 2015).

In the case of spatial differentiation (estimated) of the incidence of tuberculosis, we see an even greater impact on a successful transformation process of spreading of this disease (see: Arinaminpathy, Dye, 2010; Michalski, 2016; Walls, Shingadia, 2007). The best situation characterizes countries which successfully implemented reforms (plus Albania). Poland is the last country in the group of countries with the lowest level of tuberculosis incidence (Fig. 14).

Countries in Eastern Europe and the former Soviet Union are amongst those affected the most by the HIV/AIDS epidemic. In view of the above, also this disease has been included in the study. Since 


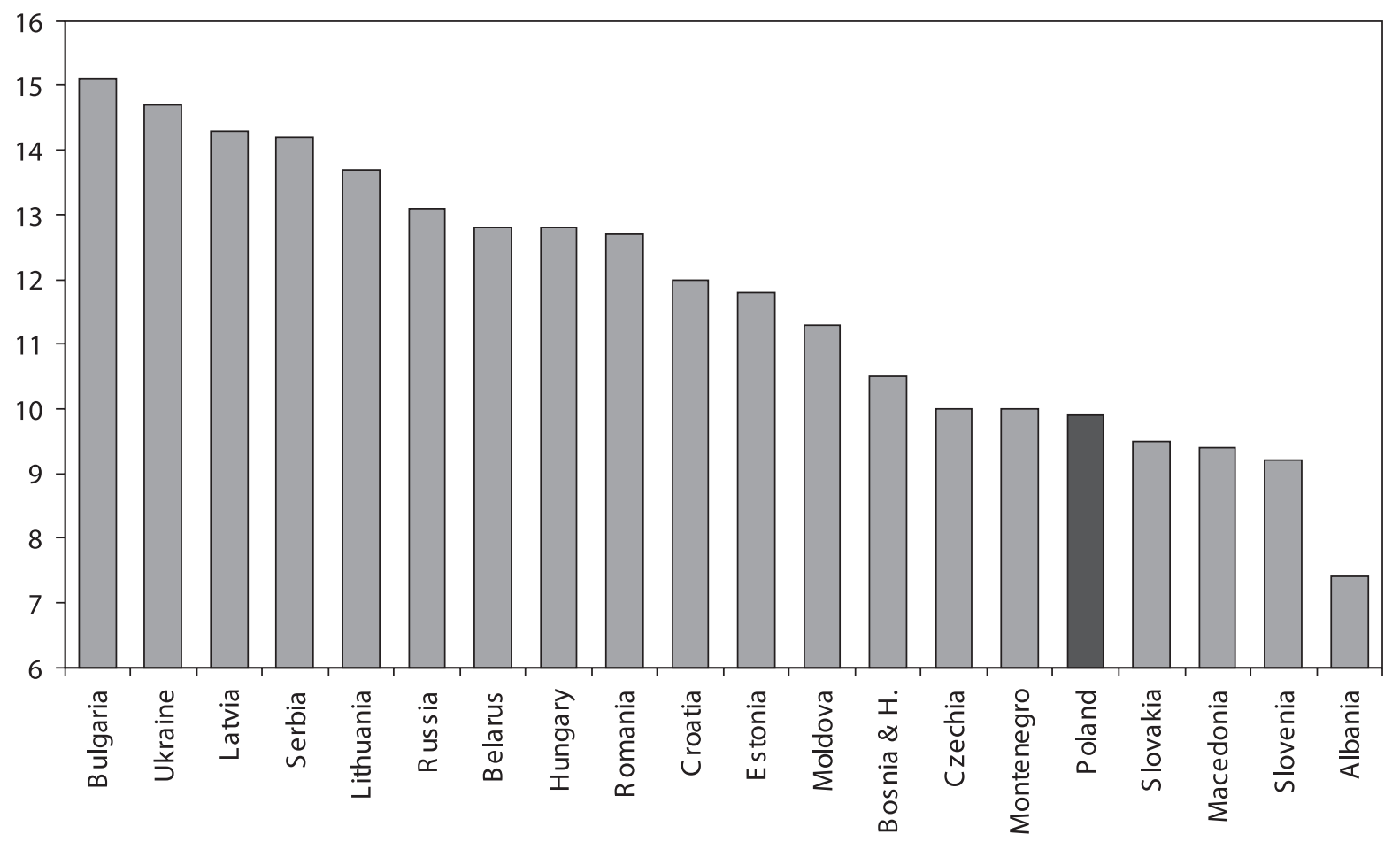

Fig. 12. The diversity of the crude death rate per 1,000 in European post-Communist countries in 2014 Source: World Bank Open Data (indicator code: SP.DYN.CDRT.IN).

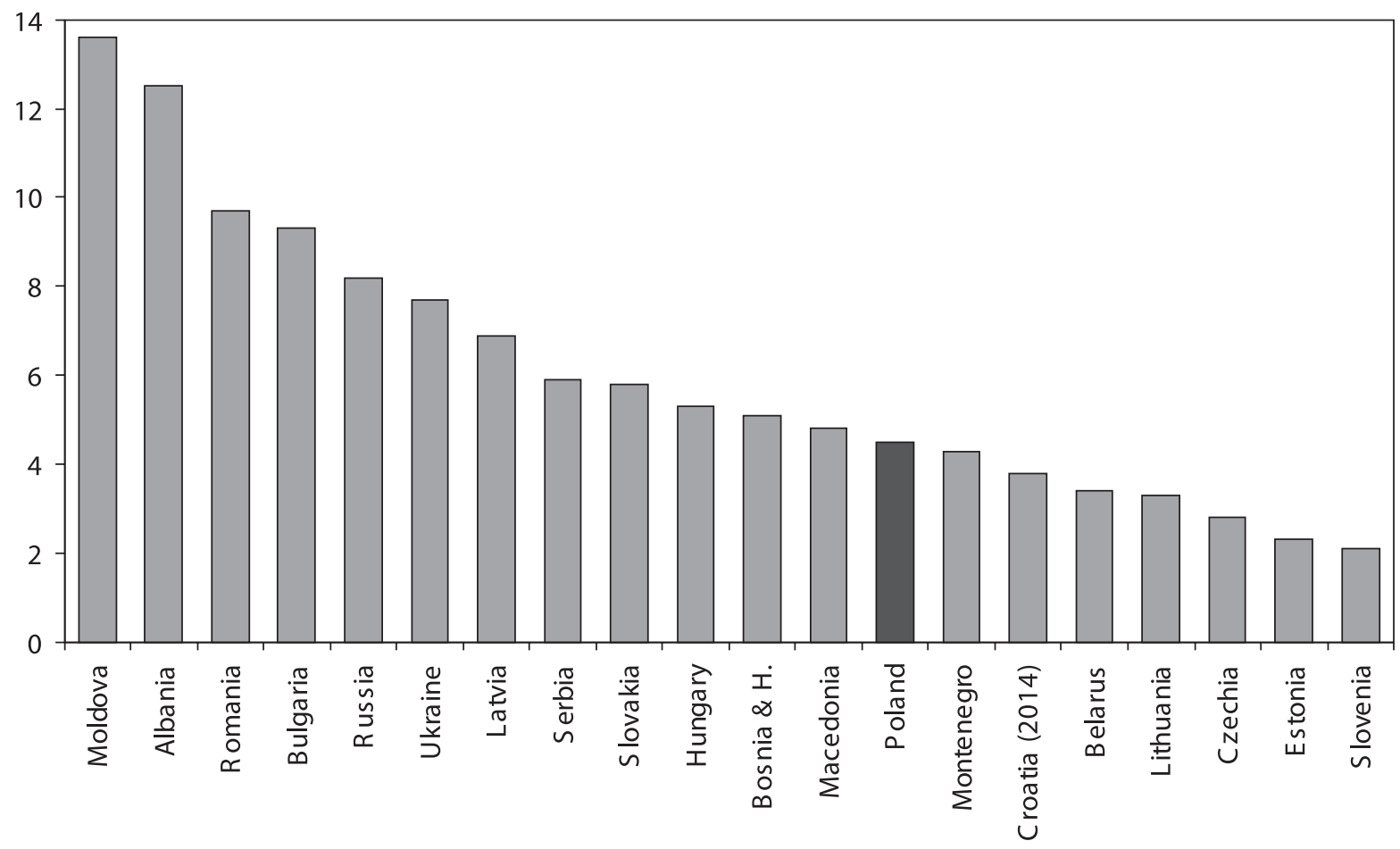

Fig. 13. The diversity of the infant mortality rate per 1,000 live births in European post-Communist countries in 2014 Source: World Bank Open Data (indicator code: SP.DYN.IMRT.IN).

the detection rate of HIV is incomplete and largely depends not only on spreading of the disease, but also on the state's policy on accessibility of detection tests and on the society's attitudes to seropositive persons, a decision was made to analyse not only HIV infections but also AIDS.

For the reasons given above, it is difficult to compare the number of patients with HIV between countries. Data on the number of AIDS cases are more 


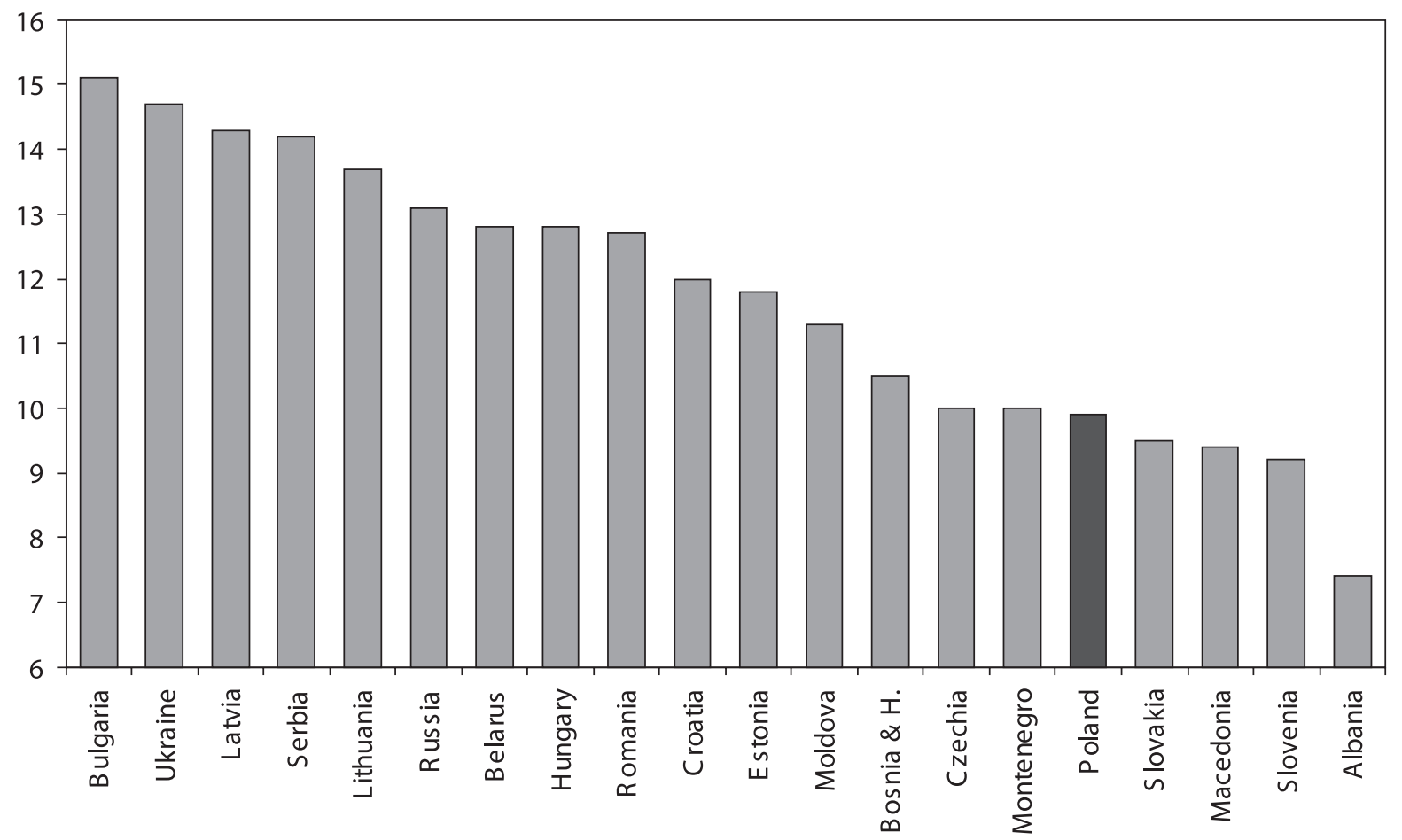

Fig. 14. The diversity of estimated ${ }^{12}$ incidence of tuberculosis per 100,000 people in European post-Communist countries in 2014

Source: HFA-DB... (indicator code: E040302.T).



Fig. 15. The diversity of the incidence of AIDS per 100,000 people in European post-Communist countries in 2014 Source: Russia: Национальный..., 2016; rest countries: HFA-DB... (indicator code: E050312.T).

reliable, and these data were compared (Fig. 15). Can say that Poland has an very good situation in comparison to other European post-Communist countries, with the worst being in countries of the former
USSR (Gokengin et al., 2016; Hamers, Down, 2003; von Zachorka, 2003).

12 For details of estimation methods see: Global..., 2016. 


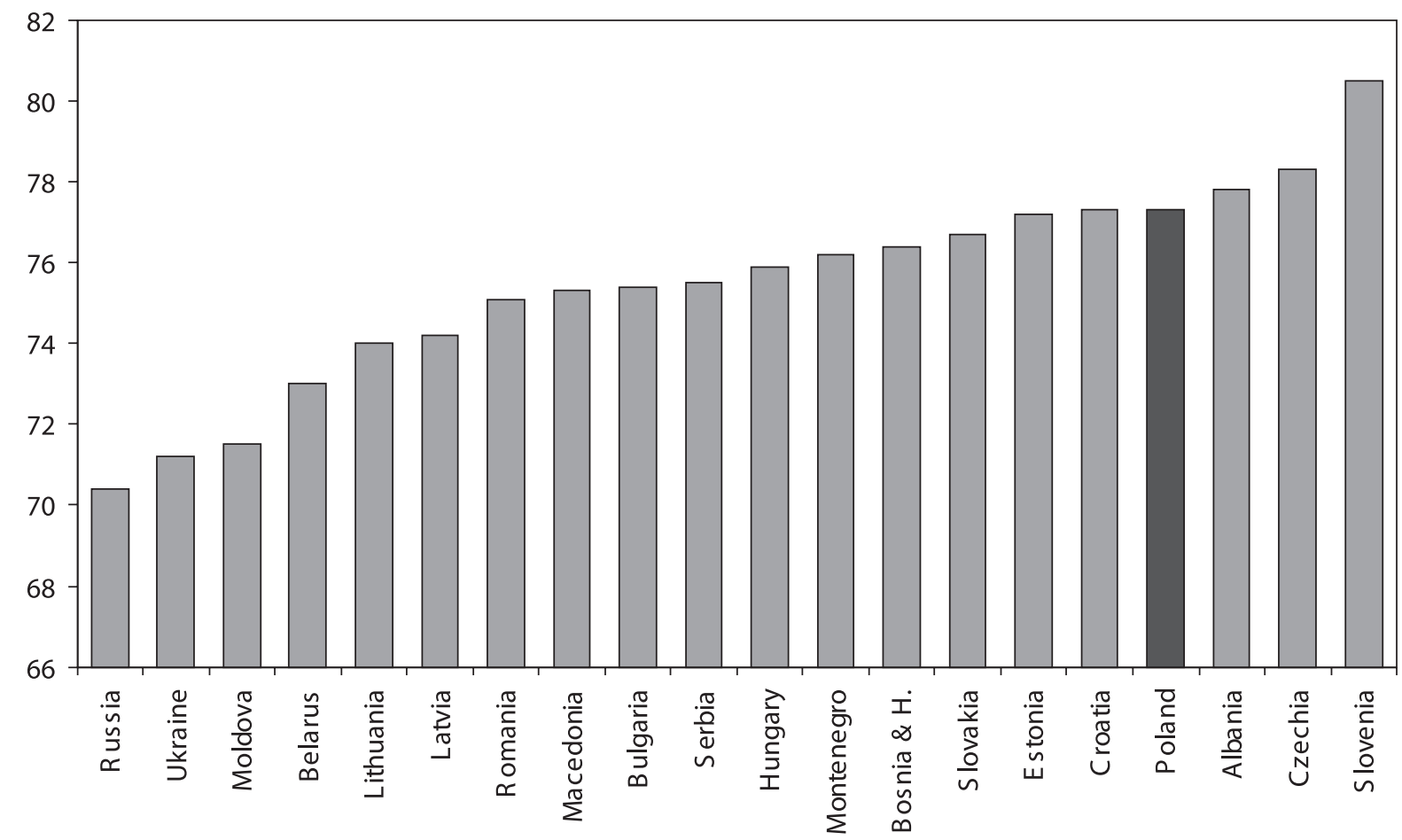

Fig. 16. The diversity of life expectancy at birth [years] for both sexes in European post-Communist countries in 2014 Source: World Bank Open Data (indicator code: SP.DYN.LE00.IN).

Most Eastern European countries for many years have had much higher premature mortality rates for males than for females (Michniewicz-Ankiersztajn et al., 2013; Michalski, 2010; Watson, 1995), and in this respect Poland is typical. Fig. 16 synthetically shows life expectancy at birth [years] for both sexes together. We see that in this respect the situation in Poland is one of the best. Equally long life expectancy at birth is characteristic of other post-Communist countries which successfully carried out the process of transformation. Yet the case of Albania raises eyebrows about the reliability of statistical data.

\section{Summary}

The health situation of the Polish population is relatively good. This is clearly seen when comparing the crude death rate and the standardized death rate. If in 2005 the crude death rate in Poland was 965 deaths per 100,000 population, in 2014 it was less by 13 . At the same time, the standardized death rate dropped by as many as 168 (from 873 deaths per 100,000 population to 705 deaths) (Kuropka, 2015). Analysing the diversity of the health situation of the population of Poland on the basis of the data presented in the study, it is difficult to find general spatial regularities.

Trying to place Poland in the theory of epidemiological transition (Wróblewska, 2009), we can conclude that Poland is at the hybrid stage, similarly to those European post-Communist countries that have successfully implemented political reforms and have become members of the European Union, with reservations for Bulgaria, Estonia, Lithuania, Latvia and Romania). However, the health situation in Poland in comparison to the wealthy countries of the European Union, it is still, unfortunately, much worse.

\section{References}

Abdulraheem I.S., Jimom A.A.G., Oladipo A.R., 2011, Gender differential in life expectancy: trends, determinants and empirical findings, Journal of Peace, Gender and Development Studies, 1(1), 15-27.

Aleshina H., Redmond G., 2005, How High Is Infant Mortality in Central and Eastern Europe and the Commonwealth of Independent States? Population Studies, 59(1), 39-54.

Arinaminpathy N., Dye Ch., 2010, Health in financial crises: economic recession and tuberculosis in Central and Eastern Europe, Journal of the Royal Society Interface, 7(52), 1559-1569.

Bąk M., 2006, Europa Środkowa i Wschodnia wobec wyzwania transformacyjnego, Wydawnictwo Uniwersytetu Gdańskiego, Gdańsk.

Balázs P., Bozóki A., Catrina Ş., Gotseva A., Horvath J., Limani D., Radu B., Simon Á., Szele Á., Tófalvi Z., Perlaky-Tóth K., 2014, 25 years after the fall of the Iron Curtain. The state of integration of East and West in the European Union, Publications Office of the European Union, Luxembourg. 
Bank Danych Lokalnych GUS, Główny Urząd Statystyczny, Warszawa, https://bdl.stat.gov.pl/BDL/start [29.11.2046]

Baza Demografia GUS, Główny Urząd Statystyczny, Warszawa, http://demografia.stat.gov.pl/bazademografia/ [28.11.2016]

Bobak M., Pikhart H., Rose R., Hertzman C., Marmot M., 2000, Socioeconomic factors, material inequalities and perceived control in self-related health: cross-sectional data from seven post-communist countries, Social Science \& Medicine, 51(9), 1343-1350.

Brainerd E., 1998, Market Reform and Mortality in Transition Countries, World Development, 26(11), 2013-2027.

Domański B., 2005, The Economic Performance and Standard of Living of Post-Communist European Countries Since 1989: Factors and Processes Behind, Geographia Polonica, 78(2), 107-126.

Florescu-Ciobotaru M., 2006, Analiză comparativă a reformei proprietății în țările Europei Centrale şi de Est (Bulgaria, Cehia, Polonia, România, Slovacia, Ungaria), Jurnalul Economic, IX(20), 45-59.

Global Tuberculosis Report 2016, 2016, World Health Organization, Geneva http://www.who.int/tb/publications/global_report/en/index.html [05.01.2017].

Gokengin D., Oprea C., Uysal S., Begovac J., 2016, The growing HIV epidemic in Central Europe: a neglected issue? Journal of Virus Eradication, 2(3), 156-161.

Gruźlica w Polsce. Biuletyn IGiChP - 2016, 2016, Instytut Gruźlicy i Chorób Płuc, Warszawa, http://www.igichp.edu. $\mathrm{pl} /$ [22.11.2016].

Grzelak-Kostulska E., Hołowiecka B., Michniewicz-Ankiersztajn H., 2012a, Europe: de grands écarts dans l'espérance de vie, Population \& Avenir, 706, 14-17.

Grzelak-Kostulska E., Hołowiecka B., Michniewicz-Ankiersztajn H., 2012b, La santé en Europe: Les raisons des différences d'espérance de vie, Population \& Avenir, 707, 14-17.

Hamers F.F., Down A.D., 2003, HIV in central and eastern Europe, Lancet, 361, 1035-1044.

HFA-DB: European Health for All database, WHO Regional Office for Europe, Copenhagen, http://data.euro.who.int/ hfadb/ (updated: July 2016) [19.11.2016].

Hu Y., van Lenthe F.J., Mackenbach J.P., 2015, Income inequality, life expectancy and cause-specific mortality in 43 European countries, 1987-2008: a fixed effects study, European Journal of Epidemiology, 30(8), 615-625.

Informacja o rozmiarach i kierunkach czasowej emigracji z Polski w latach 2004 - 2015, 2016, GUS, Warszawa, http://stat. gov.pl/obszary-tematyczne/ludnosc/migracje-zagraniczne-ludnosci/informacja-o-rozmiarach-i-kierunkach-emigracji-z-polski-w-latach-20042015,2,9.html [19.11.2016].

International Statistical Classification of Diseases and Related Health Problems 10th Revision (ICD-10) - WHO Version for, 2016, http://apps.who.int/classifications/icd10/ browse/2016/en [10.11.2016].

Komunikat Głównego Inspektora Sanitarnego z dnia 16 października 2015 r. w sprawie Programu Szczepień Ochronnych na rok 2016, 2015, Dziennik Urzędowy Ministra Zdrowia, Poz. 63, http://dziennikmz.mz.gov.pl/DUM_MZ/2015/63/ akt.pdf [12.12.2016].
Kuropka I., 2015, Umieralność i trwanie życia w Polsce i wybranych krajach europejskich, [in:] Z. Strzelecki (ed.), Sytuacja demograficzna Polski. Raport 2014-2015, Rządowa Rada Ludnościowa, Warszawa, 199-228.

Luty M., 2003, Cause of Male Excess Mortality: Insights from Cloistered Population, Population and Development Review, 29(4), 647-676.

Masuy-Stroobat G., 2006, The Determinants of Infant Heath and Mortality, [in:] G. Castelli, J. Vallin, G. Wunsh (eds.), Demography: Analysis and synthesis. A Treatise in Population Studies. Vol. 2., Elsevier, Amsterdam-Boston-HeidelbergLondon-New York-Oxford-Paris-San Diego-San Francisco-Singapore-Sydney-Tokyo, 71-79.

Meslé F., 2004, Mortality in Central and Eastern Europe: longterm trends and recent upturns, Demographic Research, 2(3), 45-70.

Michalski T., 2006, A Geographic Approach to the Transformation Process in European Post-Communist Countries, [in:] T. Michalski (ed.), The Geographical Aspects of the Transforamtion Process in Central and East-Central Europe, Wydawnictwo “Bernardinum”, Gdynia-Pelplin, 7-26.

Michalski T., 2010, Sytuacja zdrowotna w europejskich krajach postkomunistycznych $w$ dobie transformacji, Wydawnictwo Uniwersytetu Gdańskiego, Gdańsk.

Michalski T., 2012a, Przemiany w liczbie ludności i ruchu rzeczywistym w Europie Środkowej i Środkowo-Wschodniej w okresie transformacji, Wydawnictwo „Bernardinum”, Pelplin.

Michalski T., 2012b, Przemiany w umieralności w Europie Środkowej i Środkowo-Wschodniej w okresie transformacji, Wydawnictwo „Bernardinum”, Pelplin.

Michalski T., 2016, The differentiation of the health situation in European post-Communist countries after 1990, Geography and Tourism, 4(1), 33-42.

Michniewicz-Ankiersztajn H., Grzelak-Kostulska E., Hołowiecka B., 2013, Terytorialne zróżnicowanie przyczyn obciążenia chorobami w populacji wybranych krajów europejskich na tle czasu trwania życia, Journal of Heath Science, 3, 165-177.

Philipov D., Dorbritz J., 2003, Demographic consequences of economic transition in countries of central and eastern Europe, Council of Europe Publishing, Strasbourg Cedex.

Pietrzyka D., Gadzinowski J., 2007, Opieka perinatalna w krajach Europy Środkowej i Wschodniej, Kliniczna Perinatologia i Ginekologia, 43(7), 7-17.

Ram B., 1993, Sex differences in mortality as a social indicator, Social Indicator Research, 29(1), 83-108.

Shakarishvili G. (ed.), 2005, Decentralization in Healthcare. Analyses and Experiences in Central and Eastern Europe in the 1990s, Local Government and Public Service Reform Initiative, Open Society Institute - Budapest, Budapest.

Sonnenberg P., Glynn J.R., Fielding K., Murray J., Godfrey-Faussett P., Shearer S., 2005, How Soon after Infection with HIV Does the Risk of Tuberculosis Start to Increase? A Retrospective Cohort Study in South African Gold Miners, Journal of Infectious Diseases, 191(2), 150-158.

Staehr K., 2011, Democratic and Market-Economic Reforms in the Postcommunist Countries. The Impact of Enlarge- 
ment of the European Union, Eastern European Economics, 49(5), 5-28.

Szczuka I., 2000, Gruźlica w Polsce i na świecie u progu trzeciego tysiąclecia, Przegląd Epidemiologiczny, 54(1-2), 9-24.

Szczyt M., 2006, Tendencje zmian umieralności niemowląt w Polsce w latach 1970-2002, Prace Statystyczne i Demograficzne, Zeszyty Naukowe Akademii Ekonomicznej w Poznaniu, 69, 60-80.

Sztompka P., 2004, Eastern Europe: At the Crossroads of Three Historical Processes, [in:] M. Niezgoda (ed.), The Consequences of Great Transformation, Wydawnictwo UJ, Kraków, 14-19.

Walls T., Shingadia D., 2007, The epidemiology of tuberculosis in Europe, Archives of Disease in Childhood, 92(8), 726-729.

Watson P., 1995, Explaining rising mortality among men in Eastern Europe, Social Science \& Medicine, 41(7), 923--34.

World Bank Open Data, World Bank, Washington, http://data. worldbank.org/ [02.01.2017]

Wróblewska W., 2009, Teoria przejścia epidemiologicznego oraz fakty na przełomie wieków w Polsce, Studia Demograficzne, 1/155, 101-159.

Zachorka von M., 2003, HIV/AIDS in Eastern Europe, MMS Bulletin\#88, http://www.medicusmundi.ch/de/bulletin/ mms-bulletin/gesundheit-im-umbruch/-1/hiv-aids-ineastern-europe [12.12.2016].

Zakażenia HIV i zachorowania na AIDS w Polsce, Zakład Epidemiologii Narodowy Instytut Zdrowia Publicznego Państwowy Zakład Higieny, Warszawa, http://wwwold. pzh.gov.pl/oldpage/epimeld/hiv_aids/index.htm (updated: 30.11.2016) [22.12.2016].

Zatoński W., Mikucka M., La Vecchia C., Boyle P., 2006, Infant mortality in Central Europe: effects of transition, Gaceta Snitaria, 20(1), 63-66.

Zetlin J., Mortensen L., Cuttini M., Lack N., Nijhuis J., Haidinger G., Blondel B., Hindori-Mohangoo A. and the Euro-Peristat Scientific Committee, 2015, Declines in stillbirth and neonatal mortality rates in Europe between 2004 and 2010: results from the Euro-Peristat project, Journal of Epidemiology and Community Health, 0, 1-7.

Zielonka T.M., 2014, Risk factors for tuberculosis and specific manifestations of disease, Przegląd Epidemiologiczny, 68(4), 337-343.

Национальный отчет о мерах по борьбе с ВИЧ/СПИД за 2014 год, 2014, Министерство здравоохранения Российской Федерации, Москва. 